\title{
A changing trend in diagnostic methods of Influenza A (H3N2) virus in human: a review
}

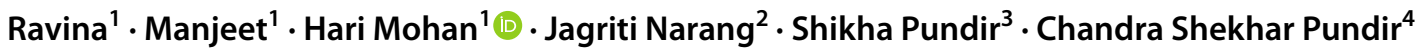

Received: 16 September 2020 / Accepted: 3 January 2021 / Published online: 20 January 2021

(c) King Abdulaziz City for Science and Technology 2021

\begin{abstract}
The influenza virus is classified into four types A, B, C, and D, but type A and B are responsible for major illnesses in people with influenza A being the only virus responsible for flu pandemics due to the presence of two surface proteins called hemagglutinin $(\mathrm{H})$ and neuraminidase $(\mathrm{N})$ on the virus. The two subtypes of influenza A virus, H1N1 and H3N2, have been known to cause many flu pandemics. Both subtypes change genetically and antigenically to produce variants (clades and subclades, also know as groups and subgroups). H3N2 tends to change rapidly, both genetically and antigenically whereas that of $\mathrm{H} 1 \mathrm{~N} 1$ generally tends to have smaller changes. Influenza A (H3N2) viruses have evolved to form many separate, genetically different clades that continue to co-circulate. Influenza $\mathrm{A}(\mathrm{H} 3 \mathrm{~N} 2)$ viruses have caused significant deaths as per WHO report. The review describes methods for detection of influenza $\mathrm{A}(\mathrm{H} 3 \mathrm{~N} 2)$ viruses by conventional serological methods as well as the advanced methods of molecular biology and biosensors. All these methods are based on different parameters and have different targets but the goal is to improve specificity and increase sensitivity. Amongst the molecular methods, real-time polymerase chain reaction (RT-PCR) is considered a gold standard test due to its many advantages whereas a number of other molecular methods are time-consuming, complex to perform or lack specificity. The review also considers bio-sensing methods for simple, rapid, highly sensitive, and specific detection of H3N2. The classification and principle of various H3N2 biosensors are also discussed.
\end{abstract}

Keywords Influenza A $\cdot$ H3N2 $\cdot$ Biosensor $\cdot$ Real-time PCR $\cdot$ Hemagglutinin

\section{Introduction}

Influenza is a respiratory disease that infects between 5 to $15 \%$ of the global population annually and responsible for high mortality across the globe (Stöhr 2002). According to the latest report of the World Health Organization (WHO), the cases of Influenza A(H3N2) viruses are present all over

Hari Mohan

harimohan.cmbt@mdurohtak.ac.in

$\triangle$ Chandra Shekhar Pundir

chandraspundir@gmail.com

1 Centre for Medical Biotechnology, Maharshi Dayanand University, Rohtak, Haryana 124001, India

2 Department of Biotechnology, Jamia Hamdard, New Delhi, India

3 Liggins Institute, The University of Auckland, Auckland, New Zealand

4 Department of Biochemistry, MaharshiDayanand University, Rohtak, Haryana 124001, India the world affecting more than $30 \%$ of the world population (WHO update-362). The WHO estimates that these infections result in 250,000-500,000 deaths every year (Vemula et al. 2016). The Influenza A(H3N2) virus caused many outbreaks and was responsible for the 1968 pandemic. During this pandemic, genetic re-assortment happened in the avian influenza virus, which caused millions of deaths worldwide, when got introduced in the human population (Shim et al. 2017).

The influenza virus is classified into 4 types (A, B, C and D) of which influenza A and B cause illness but influenza A, a member of Orthomyxoviridae family, causes pandemic. Influenza A is further classified into different subtypes based on the presence of hemagglutinin and neuraminidase surface antigen. (CDC 2020) According to the CDC report, 18 different subtypes of hemagglutinin $(\mathrm{H})$ and 11 different neuraminidase $(\mathrm{N})$ have been reported, which makes 198 combinations, of which only 131 are in circulation. H1N1 and $\mathrm{H} 3 \mathrm{~N} 2$ are the major subtypes of the influenza virus that infect people at a large number. The focus is on H3N2

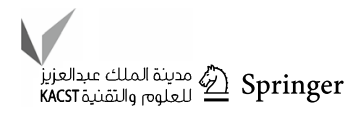


subtype due to its rapid antigenic and genetic changes which are responsible for severe infections. Influenza $\mathrm{A}(\mathrm{H} 3 \mathrm{~N} 2)$ virus binds with an $\alpha-2,6$ glycosidic bond between galactose and sialic acid, as shown in Fig. 1. But its ability to bind with avian receptors was also reported during 1999 isolates. $\mathrm{H} 1 \mathrm{~N} 1$ and $\mathrm{H} 3 \mathrm{~N} 2$ viruses have many differences at the gene sequence level, which are also inherited at the amino acid level. A comparison was made between these two virus sequences with the help of a decision tree and apriori algorithm and concluded that both subtypes are very similar but differences in their amino acid composition are present (Jang et al. 2016). In another study, they tested immunized rabbit sera with $\mathrm{H} 1$ antigen, which did not show any activity against the Influenza A(H3N2) virus. Similarly, when the rabbit was immunized with $\mathrm{H} 3$ antigen, no significant $\mathrm{HI}$ titer was found against Influenza $\mathrm{A}(\mathrm{H} 1 \mathrm{~N} 1)$ virus. This clearly explains the antigenic difference between the two strains (Wang et al. 2006). From 2001 to 2002, the affinity reduced for an avian receptor but regained in 2003 the ability to bind with $\alpha-2,3$ sialylated glycans prefer to bind with avian receptors (Wang et al. 2015). Thus, with time, mainly from 1991 to 1998, some changes occurred due to antigenic drift in Influenza A(H3N2) virus, which made it different from the 1968 pandemic. According to a study of genomewide analysis of 286 Influenza $\mathrm{A}(\mathrm{H} 3 \mathrm{~N} 2)$ viruses, the rate of mutation is more for surface antigens (hemagglutinin, neuraminidase) and PB1-F2 proteins (Westgeest et al. 2014). Another study reported local fitness landscape for the antigenic binding site (B), one of the five binding sites (A-E) that also form a part of receptor-binding site and is evolving as they proved with the use of deep mutational scanning of mutant's library of viruses. The local fitness landscape is a study from genotype to phenotype in an available genetic variant of the virus. Mutations in amino acid sequences at the receptor-binding site affect the local fitness landscape of antigenic binding site B (Wu et al. 2020). With time, this subtype has changed its receptor-binding properties and showed a reduced affinity for sialic acid analogs receptor of the respiratory cell. Since 1968, numerous changes have occurred in the Influenza A(H3N2) virus genetically and antigenically through antigenic drift and many changes also occurred in the WHO-recommended vaccine strains over some time (Lin et al. 2017). The new substitutions affected its neutralization activity and helped in escaping from humoral immunity by gaining additional $\mathrm{N}$-glycosylation site, an asparagine (Asn) at position 45 and 144 (Ushirogawa et al. 2016). Another study reported that Influenza $\mathrm{A}(\mathrm{H} 3 \mathrm{~N} 2)$ virus has maintained the human-type specificity, but has shifted their preference to receptors consisting of extended poly- $N$-acetyl-lactosamine (poly-LacNAc) chains,

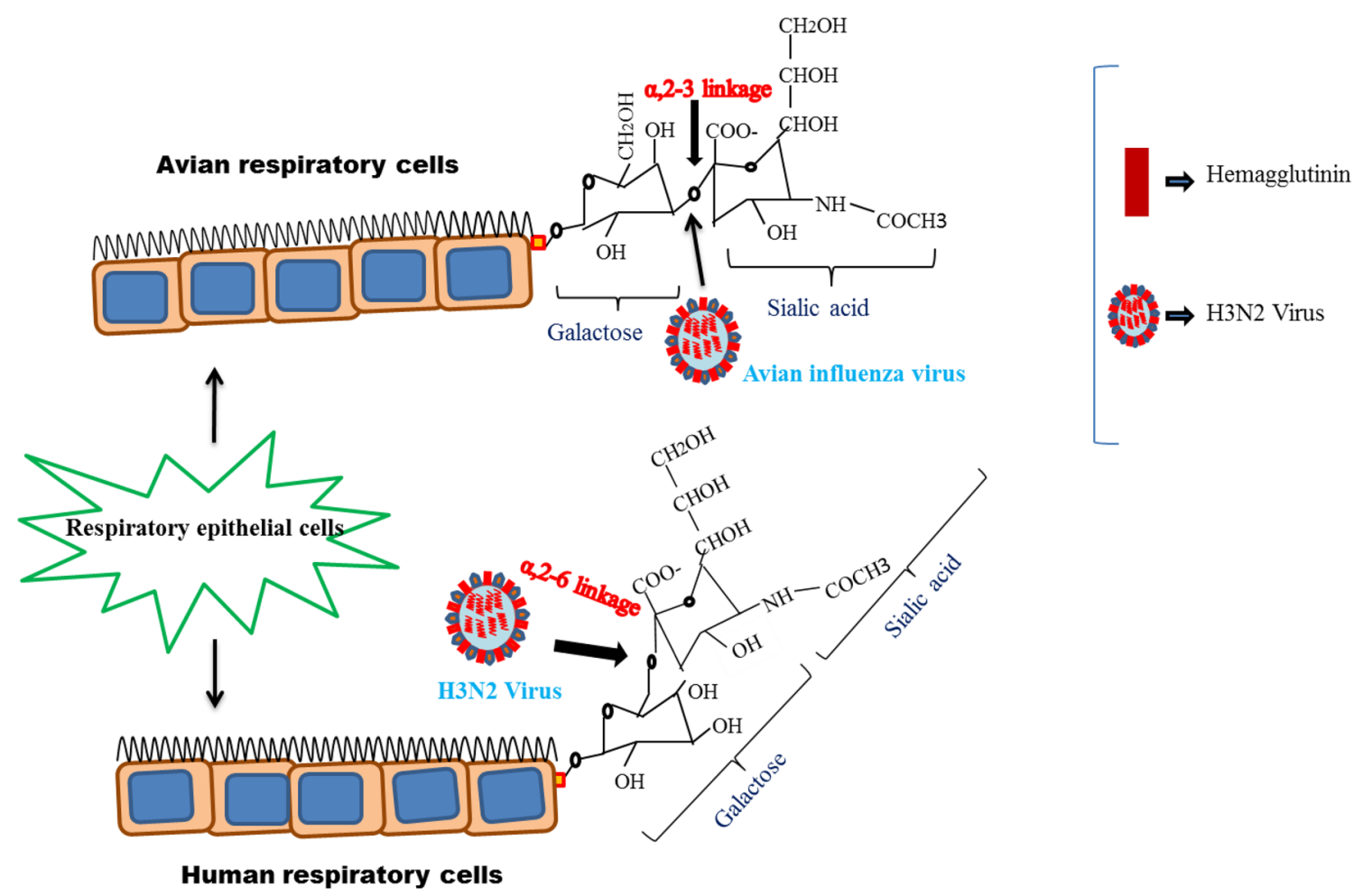

Fig. 1 An image showing different receptor specificities for avian influenza virus and human influenza virus. Birds respiratory cells have receptors ( $\alpha-2,3$ bond between sialic acid and galactose) for avian influenza virus and human respiratory cells have different receptors $(\alpha-2,6$ bond between sialic acid and galactose) 
a specificity shared with the 2009 pandemic H1N1 (Cal/04) hemagglutinin (Peng et al. 2017). The symptoms resemble other respiratory viruses, which included headache, sore throat, fever, nasal discharge, coughing, nasal discharge, and myalgia. In the case of severity, pneumonia and bronchitis could happen, which finally leads to death. The infected patient produces ultrafine aerosol particles having a live virus that was proved in a study in which samples were collected by air samplers (Lednicky and Loeb 2013). H3N2 is more severe than $\mathrm{H} 1 \mathrm{~N} 1$ in the case of $\mathrm{C}$-reactive protein, fever, and leukopenia-type diseases (Kaji et al. 2003). In a study, it is proved that $\mathrm{H} 3$ is more immunogenic than H1 (Treanor et al. 2006). All these evidences suggest that the rapid evolution of the virus produces significant challenges in the recognition and diagnosis of these diseases (Blackburne et al. 2008). Therefore, researchers are constantly finding new ways and methods for the faster characterization of Influenza A(H3N2) virus, as timely diagnosis of H3N2 is essential for early treatment. Several detection methods are available, but Real-Time PCR is a standard test as recommended by the WHO. According to the latest report of $\mathrm{WHO}$, the cases of $\mathrm{H} 3 \mathrm{~N} 2$ are present all over the world affecting more than $30 \%$ of the world population (Influenza Update-362-WHO). Once this has been determined, then a rapid test can be developed solely to monitor the clade (group) and subclade (subgroup) during a pandemic. A flow diagram to demonstrate similarity and different requirements of the methods has been included. We describe here various methods for the detection of H3N2.

\section{Detection techniques of Influenza A(H3N2) virus}

Influenza virus detection techniques have been classified into four categories: traditional methods, serological methods, advanced quick methods, and bio-sensing methods. Virus culture comes into the class of traditional methods. The serological techniques include immunofluorescence assays, complement fixation, immunodiffusion test, virus neutralization method, hemagglutination method, rapid antigen testing, etc. It has been observed that instead of nasal and throat swabs, nasopharyngeal swabs yield higher in rapid influenza detection (CDC 2018). After serological methods, advance and quick methods are discussed which are based on the molecular biology of elements. It includes rapid influenza technique, Real-Time PCR, multiplex PCR, NonPCR-based RNA-specific detection methods, nucleic acid sequence-based amplification (NASBA), and conventional PCR. The bio-sensing method includes optical biosensors, giant magneto-resistance biosensors, aptamer-based biosensors, and electrochemical biosensors. We present here a comprehensive discussion on all the methods available for the detection of H3N2 with an emphasis on bio-sensing methods. Earlier, we reported various detection methods for H1N1 (Chauhan et al. 2013; Ravina et al. 2020). A flow diagram is shown explaining important parameters about the methods in Fig. 2.

\section{Traditional methods}

\section{Cell culture}

The culturing of the virus was started in the 1940s and is considered to be the oldest conventional and recommended method for the diagnosis of influenza to study antigen characterization of new strains (McMullen et al. 2016). Although it is an old method, it is followed by the researchers for the surveillance, virus antigen characterization, and the isolation of the virus. The embryonated eggs or mammalian cells are used for the propagation of the influenza virus for its recovery from clinical samples. In this method, the infectious samples are inoculated into the embryonated eggs or permissive cell lines and followed by one-week propagation (up to 10 days). Afterwards, the cytopathic effect is observed, and virus infection is checked by different methods, such as using immunofluorescence microscopy and molecular methods (Vemula et al. 2016). This viral isolation technique is usually executed on formerly established cell lines, such as A549, rhesus monkey kidney (LLC MK2), Madin Darby canine kidney (MDCK), buffalo green monkey kidney (BGMK), and mink lung epithelial cell line (Mv1Lu), or primary cell lines, such as African green monkey kidney (AGMK) or rhesus monkey kidney (RhMK). MDCK cell lines are usually preferred for $\mathrm{H} 3 \mathrm{~N} 2$, but recently it has been observed that replicating efficiency is poor in these cell lines and sharply build up either NA or HA mutations when in vitro propagation is done before antigenic testing (Chambers et al. 2014). MDCK cells have both $\alpha 2,6$ and $\alpha 2,3$-linked SA receptors and allow both avian and human influenza viruses to be cultured from this cell line with high HA titers (hemagglutination). Nevertheless, during the past years, a favorable binding of Influenza $\mathrm{A}(\mathrm{H} 3 \mathrm{~N} 2)$ virus isolates to $\alpha 2,6$-linked SA molecule has been observed (Medeiros et al. 2001; Yang et al. 2015; Parker et al. 2016). But the amount of $\alpha-2,6$ receptors on MDCK cells is low as compared to human respiratory cells. Hence, it is concluded that these cells are not good for $\mathrm{H} 3 \mathrm{~N} 2$ virus propagation. To solve this problem, a new version of MDCK SIAT1 with more $\alpha 2,6$-sialic acid on its surface was developed. Human CMP- $N$-acetylneuraminate beta-galactoside was used for the transfection of MDCK cells, to make them MDCK SIAT1 cells. It also helped in increasing the sensitivity for neuraminidase inhibitors with the over-expression of $\alpha 2,6$-sialyltransferase in MDCK

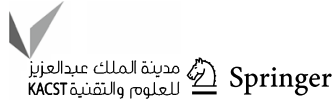




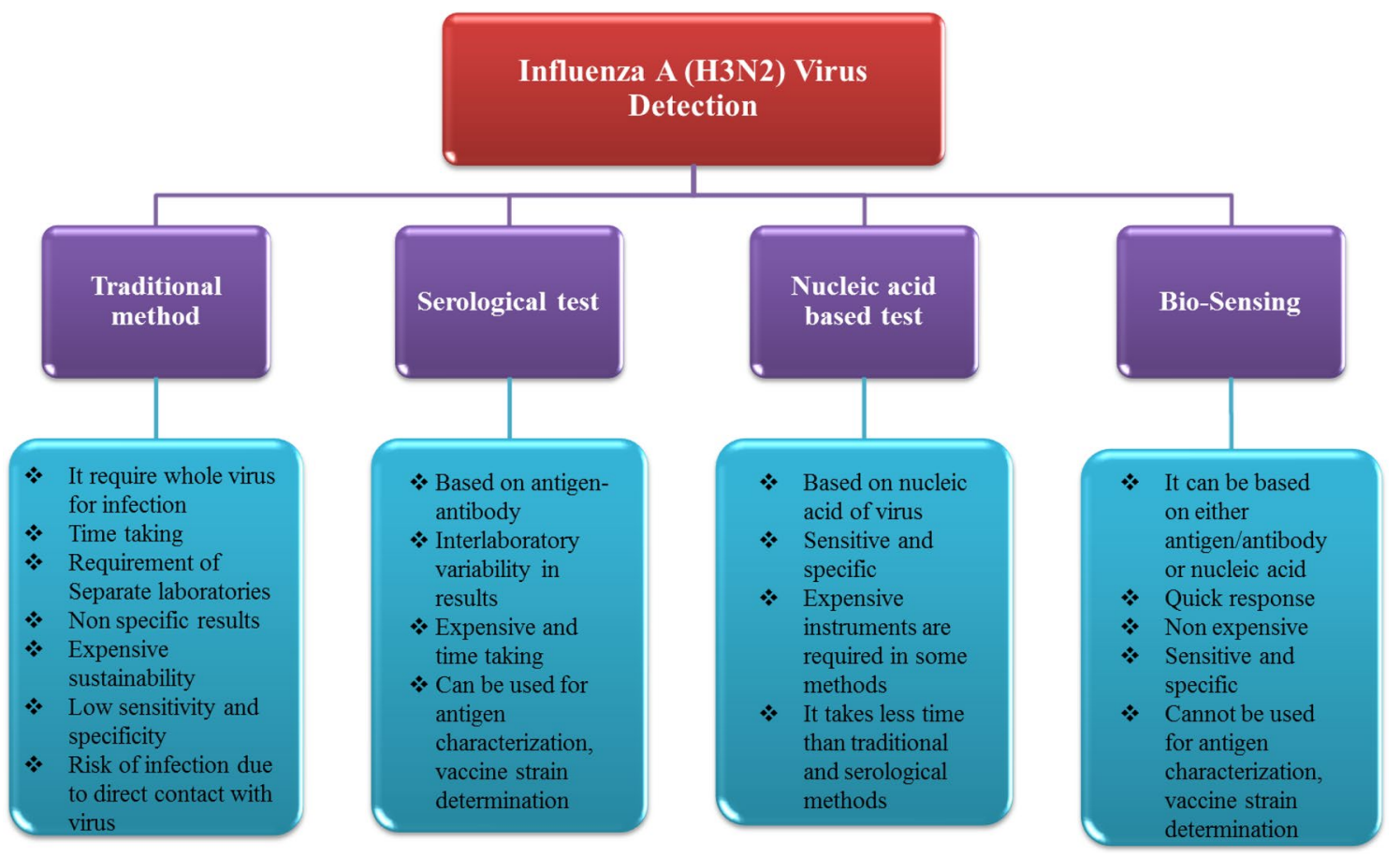

Fig. 2 A flow diagram to demonstrate similarity and different requirements of the methods is shown. All methods have their specific role in detection but selection of method is done according to the requirement

cells (Matrosovich et al. 2003). It was also reported that viruses that emerged in 2001, when compared with 1968 isolates of Influenza $\mathrm{A}(\mathrm{H} 3 \mathrm{~N} 2)$ virus, showed a decreased ratio of MDCK cell infection in comparison with MDCK SIAT1 cells (Barr et al. 2010; Oh et al. 2008). Although, this method is very useful for the surveillance, virus antigen characterization, and the isolation of the virus. But cannot be used for detection purpose due to its laborious procedure and the requirement of sustainable for virus culturing which cannot be maintanied everywhere.

\section{Serological methods}

These assays are generally used to diagnose antibodies response against the influenza virus. The serological tests include hemagglutination inhibition assay (HAI), virus neutralization assay (VN) or microneutralization, single radial hemolysis (SRH), complement fixation assay, enzyme-linked immunoabsorbent assay (ELISA), and Western blotting (Li et al. 2017). Due to the sample collection complexity, such as paired serum samples, these tests are not recommended routinely. The first swab should be collected at the onset of infection, and the second swab must be taken 2-4 weeks post infection. However, this test is cheap and simple, but the specificity of this assay is not satisfactory (CDC 2020). The following serological tests have been reported.

\section{Virus neutralization (VN) assay}

This technique measures the induction of antibodies specific to the virus, which follows vaccination or natural infection. It is performed routinely for antibody titer detection of either avian or seasonal influenza virus strains. This test is chiefly based on virus-specific antibodies' ability to neutralize the virus. The virus neutralization titer is the reciprocal value of the highest serum dilution at which infection is blocked. Due to the requirement of highly specialized laboratories (BSL2 + and BSL3 laboratories), the application of this test does not apply for routine diagnostics. However, this test is more sensitive than the HAI assay (Li et al. 2017).

\section{Enzyme-linked immunoassay (ELISA)}

ELISA tests are accessible for the diagnostic purpose since the 1990s that possesses high specificity and sensitivity (Leirs et al. 2016). The major drawback of this test is its low specificity in comparison to nucleic acid-based tests. In conventional tests, the color change is observed due to the interaction of specific antigen-antibody and immunocomplexenzyme linkage for viral detection (Lin et al. 2017; Barbé et al. 2009). Some scientists have worked on intensifying the sensitivity of the ELISA test using europium and gold nanoparticles. In a study by Zhang et al., europium nanoparticles were used to develop an immunoassay (ENIA), which has 
16 times more sensitivity for influenza virus A and B strain than ELISA (Zhang et al. 2014). Another study reported an ultra-sensitive colorimetric immunoassay. In this assay, gold nanoparticles (AuNPs) imitate the peroxidase role to enhance the signal. It can detect as low as 10 plaque-forming units of isolated H3N2, having sensitivity up to 500-fold, which is higher than other available kits. It is much more sensitive even in different biological media as compared to ELISA (Ahmed et al. 2016). This test helps in determining the potency of a new antiviral drug against the virus present in the patient's respiratory tract. The different dilutions of clinical samples into virus susceptible cells were used to observe the increment in viral progeny with the help of hemagglutination because the influenza virus usually has erythrocyte-binding capacity. But currently, circulating virus has a reduced affinity of hemagglutination. It was observed in the Netherlands from 1999 to 2012 when the H3N2 virus was HA deficient. Another method has been reported for monitoring influenza progeny production in quantitative virus culture, which is free of the ability to agglutinate erythrocytes. In this method, viral nucleoprotein (NP) was detected in virus culture plates by ELISA and provided good results with different isolates of A/Brisbane/059/07 (H1N1), A/Victoria/210/09 (H3N2), A (H1N1)pdm09, and other seasonal $\mathrm{A}(\mathrm{H} 1 \mathrm{~N} 1), \mathrm{H} 3 \mathrm{~N} 2$. In complementary, NP became the way to check titer because of the absence of HA activity. Many type A (H3) viruses that have circulated since 2010, failed to show HA activity and then the titer was checked only by detecting NP. In influenza seasons when non-hemagglutinating influenza A viruses circulated, the clinical trials were done using the ELISA technique that enabled efficient testing (Van Baalen et al. 2014). Although, ELISA is very specific test but it takes 2-3 days in determining the virus type. Single sample cannot be performed with ELISA which is used for batch testing to reduce the cost of test.

\section{Haemagglutinin inhibition assay}

The haemagglutinin inhibition assay is based on inhibition interaction between red blood cells receptor and glycoprotein. It is a conventional method for antigenic characterization and antibody titre determination. This technique is used for surveillance of circulating flu viruses that aid in the selection of virus strains for the vaccine. But in comparison to HAI titer $<1: 10$, an HAI titer $\geq 1: 40$ are linked to $50 \%$ or higher protection from influenza infection (Pavlova et al. 2017; Wang et al. 2017). This test faced many industrial confronts, like inconsistencies between erythrocytes batches from the same species and variations among erythrocytes from different species. The efficiency of binding of influenza HA to the host SA relies on both the SA-type and linkagetype, which connects the SA and receptor molecule through oligosaccharide moiety (Medeiros et al. 2001). Moreover,
Influenza $\mathrm{A}(\mathrm{H} 3 \mathrm{~N} 2)$ viruses are no longer able to agglutinate RBCs of aves but have the capacity of agglutinating human and guinea RBCs. Both human and guinea pig RBCs show nearly threefold more $\alpha 2,6$ than $\alpha 2,3$-linked SA molecules in comparison to avian RBCs, which indicates that the modern $\mathrm{H} 3 \mathrm{~N} 2$ viruses favorably bind to $\alpha 2,6$-linked SA molecules (Gulati et al. 2013). During surface biolayer interferometry (BLI) assays analysis, H3N2 viral binding to polyacrylamide-linked polyvalent receptor analogues of $\alpha 2,3$-sialyl lactosamine and $\alpha 2,6$-sialyl lactosamine demonstrate an analogous trend of recent Influenza A(H3N2) virus's positive binding to $\alpha 2,6$-linked molecules (Peng et al. 2017). That is why many scientists nowadays use guinea pig RBCs as HAI assay targets during $\mathrm{H} 3 \mathrm{~N} 2$ virus analysis (Lin et al. 2012; Barr et al. 2010). The antibody-antigen complex formed in the SRH method instigates the extent of hemolysis areas, which are proportional to antibody's quantity. Usually, this technique is used for determining antibody titre in vaccinations and natural infections (Wang et al. 2017). SRH provides higher sensitivity than HAI assay. First, viruses were assorted with diluents or serially diluted with ferret antiserum, then pre-incubation was done for at least one hour at room temperature, afterwards freshly made cell suspension was united and seeded onto 96-well plates. Particularly, to avoid the extent of virus progeny towards adjacent cells, the TPCK-treated trypsin was removed. After a brief incubation period of $24 \mathrm{~h}$, the cells were stained using Hoechst 33,342, and the cells infected by the virus were detected using immune stain against influenza NP. Automated microscopy that uses a high-content imaging microplate reader was used to detect and quantify the NP-negative and NP-positive cells. HINT titers were resolved using the reciprocal dilutions of the anti-sera which were used to decrease the population of infected cells (ICP) by $50 \%$ in comparison to the wells, which were kept as control without serum with the help of curve fitting analysis. Traditionally, antigenic monitoring was done by $\mathrm{HI}$ assay. Influenza virus forms agglutination with RBC'S host receptors, and strain-specific animal antisera induce inhibition of agglutination. But nowadays, $\mathrm{H} 3 \mathrm{~N} 2$, unable to agglutinate with RBC, makes diagnosis more difficult as circulating viruses remain undiagnosed by HI assay. The alternate method was derived by a Highcontent Imaging-based micro-Neutralization Test (HINT) in which by the use of a low multiplicity of infection, the assay was optimized to demonstrate single-cycle infection. It is also helpful for explaining the change in HA due to amino acid substitution, which helps in immune escape. This assay can also diagnose in the host body, which may be used for virus population characterization without cell culture. This assay can be employed in viral characterization in human specimens, featuring the upcoming perspective of the assay towards the antigenic characterization of the virus population. This novel practice is an encouraging approach to

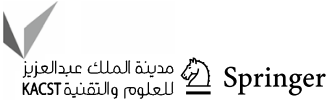


accelerate the diagnosis of antigenic drift variants between quickly developing influenza A (H3N2) viruses (CDC 2020; Jorquera et al. 2019). One major drawback of this test is the variation in inter-laboratory results. That is why other specific and sensitive methods are required.

\section{Lateral flow assay}

It is an antigen-antibody-based method exercised on a paper strip, which can detect analytes from samples. Now many modifications have been reported, in this assay, which provides better sensitivity and specificity. A dual-recognition element lateral flow assay was developed for the detection of the H3N2 virus with a detection limit of $2 \times 10^{6}$ virus particles. In this method, an aptamer tagged with biotin at $5 '-3^{\prime}$ was used with gold-conjugated less-specific antibody to detect the whole virus (Le et al. 2017). Similarly, this lateral flow assay has provided a way to detect COVID-19 quickly without the need for expensive instruments.

\section{Nucleic acid-based tests}

Nucleic acid tests (NAT) employ PCR and virus-specific RNA or DNA sequences/genetic material instead of viral antibodies or antigens. These are much susceptible and specific as compared to serological assays and can diagnose viruses in many earlier clinical samples. Antibody-based test takes time because human body cannot make antibodies instantly at a detectable level. Therefore, NAT can fill this limitation of serological methods. Different NATs are accessible for influenza virus detection in humans, and these tests include nucleic acid sequencing-based amplification (NASBA), reverse transcriptase PCR (RT-PCR), loopmediated isothermal amplification-based assay (LAMP), transcription-mediated amplification. Most of these methods take 2-4 h to complete the detection and representing the higher specificity and sensitivity as compared to the serological test (Vemula et al. 2016).

\section{RT-PCR}

This technique is considered the most powerful tool for the detection of the influenza virus. Nested primers are utilized to detect and subtype influenza virus. The results of this test present extremely high sensitivity and specificity, the greatest of all traditional detecting approaches (Gavin and Thomson 2004). The methodology of the test includes extraction of viral RNA from the specimen, RNA reverse transcription to single-stranded complementary DNA (sscDNA) by reverse transcriptase, and product amplification with fluorescent detection. RT-PCR method shows $10^{6}$ and $10^{3}$ times higher sensitivity to ELISA and cell culture methods. The process of merging several primer sets in the multiplex RT-PCR technique permits the detection of numerous respiratory viruses in a single reaction. Therefore, the key advantage of this technique is the low cost, as RT-PCR is most expensive and requires $1-8 \mathrm{~h}$ along reaction time (Koski and Klepser 2017). A multiplex one-step Real-time PCR was developed for simultaneous detection of H1N1, H3N2, and H7N9 in sputum and swab samples. Influenza type A was confirmed with the help of the matrix gene and then $\mathrm{H} 3, \mathrm{H} 7$, and $\mathrm{H} 1$ gene-specific primers were used in this test. This method could detect these viruses with $100 \%$ sensitivity and $>95 \%$ specificity with a limit of detection $5.4 \times 10^{-2} 50 \%$ tissue culture infective dose $\left(\mathrm{TCID}_{50}\right)$. A one-step multiplex real-time reverse transcriptase polymerase chain reaction (rRT-PCR) test was set up to concomitantly notice and differentiate FluA subtypes, together with a virulent disease (H1N1) 2009 virus, human seasonal H3N2 virus, and reassortant avian $\mathrm{H} 7 \mathrm{~N} 9$ virus, in a single reaction tube. Total viral RNA from viral culture or each sample was taken out, and the precise recognition of FluA virus and its subtypes was executed through a multiplex rRT-PCR assay by amplifying a specific region of HA (hemagglutinin) gene (Lee et al. 2001). In a study, multiplex RT-PCR was used for differentiation of Influenza A(H3N2) virus of Avian-Origin from Human-Origin $\mathrm{H} 3 \mathrm{~N} 2$ also with, Equine-Origin $\mathrm{H} 3 \mathrm{~N} 8$ and H1N1/2009 using four primers set for HA gene amplification (Wang et al. 2017). MDCK cells were used for isolation of FluA virus by conventional methods using BSL-2 laboratory for pandemic (H1N1) 2009 and human Influenza $\mathrm{A}(\mathrm{H} 3 \mathrm{~N} 2)$ virus, and BSL-3 laboratory was used for the reassortant avian H7N9 virus. Each fresh sample was inoculated with MDCK cells. The cultured cells were harvested by centrifuging at low speed $(8000 \mathrm{~g} / \mathrm{min})$ by observing the cytopathogenic effect of virus-infected cells. The harvested cells were used for sequence assay and detected using $\mathrm{H} 3$ gene-specific primers in PCR. This multiplex test offered a quick and simple technique for clinical diagnostics and viral observation in influenza A and its subtypes (Cui et al. 2016). A commercialized dual priming oligonucleotide-based multiplex PCR method was developed for influenza virus A, B, and subtypes of A (H1N1, H3N2) detection (Seeplex ${ }^{\circledR}$ Influenza A/B OneStep Typing, Seegene, Seoul, Korea). In this method, two primers linked with polydeoxyinosine were used and can differentiate between influenza A and B and different subtypes of A (H3, H1, and H1N1-2009 (Kim et al. 2013). Reverse transcriptase Real-time PCR is also the best choice for SARS-CoV-2 detection nowadays, as recommended by WHO in 2020.

\section{LAMP}

LAMP is a DNA loop-mediated isothermal nucleic acid amplification technique that has been fabricated for the recognition of several viruses. It is evaluated by a method of 
using a Bst polymerase (otherwise reverse transcriptase is used for RNA samples), which has high strand displacement action (Notomi et al. 2000). Two sets of primers are particularly designed to distinguish six different regions on the viral cDNA. Results are noticed by either noticing the change in colour after the addition of SYBR green or photometrically detecting the magnesium pyrophosphate by-product released after the reaction. A $100 \%$ test sensitivity has been reported for recognition of seasonal influenza A virus from $\mathrm{H} 3 \mathrm{~N} 2$ and H1N1 subtypes from clinical samples using primers for the matrix gene (Poon et al. 2005). They also used the same technique for the severe acute respiratory syndrome (SARS) corona virus detection (Poon et al. 2004). A colorimetric RT-LAMP was also developed for SARS-CoV-2 using primers against the nucleoprotein gene with sensitivity and specificity of 97.5 and $99.7 \%$. A change in color from red to yellow confirmed the presence of the virus (Thi et al. 2020).

\section{NASBA}

NASBA is an isothermal PCR-independent amplification technique, which uses a blend of three enzymes: RNAse $\mathrm{H}$, T7 RNA polymerase and avian myeloblastosis virus reverse transcriptase in sole reaction. It was well developed for the diagnosis of seasonal influenza type A and highly pathogenic avian H7N9 and H5N1 influenza A viruses. Lately, Wang et al. (2013) have generated a customized method of NASBA and referred to as a simple method for amplifying RNA targets, or SMART, for the detection of seasonal H1N1 and $\mathrm{pH} 1 \mathrm{~N} 1$ as well as Influenza $\mathrm{A}(\mathrm{H} 3 \mathrm{~N} 2)$ viruses (Wang et al. 2013). This isothermal technique employed singlestrand DNA (ssDNA) probes to assist as reporter molecules for seizing precise viral RNA (vRNA) sequences, which are consequently separated on a microfluidic chip in zero-flow circumstances. The SMART test confirmed an analytical sensitivity of up to $10^{5} \mathrm{vRNA}$ copies/ml with a test sensitivity of $98.3 \%$ and specificity of $95.7 \%$ for the detection of influenza A viruses. Influenza $\mathrm{A}(\mathrm{H} 3 \mathrm{~N} 2)$ virus-specific probe gives $95 \%$ sensitivity and $100 \%$ specificity.

\section{Bio-sensing techniques}

Biosensing techniques are the most recent development in the identification and diagnosis of the virus (Wang et al. 2011). The fabrication of a typical biosensor is based on three main components: a biological component (enzyme, protein, ssDNA, RNA, antibody/antigen, carbohydrate group, and cells), amplification/processing element, and a signal-transducing component (optical, electrical, or thermal). The mode of transduction relies on the type of physicochemical change, which results in a sensing event. A basic design of the sensor is shown in Fig. 3. Different types of sensors have been reported for detecting a variety of pathogens. These sensors are based on DNA, RNA, aptamer, PNA, protein, antigen-antibody for detecting targeted pathogens (Ravina et al. 2019; Kumar et al. 2020). Nowadays, sensors are developed with the use of aptamers which are a synthetic oligonucleotide or protein folded in three-dimensional form and can bind specifically to target non-covalently and can differentiate between targets with a single functional group (Ruscito and DeRosa 2016). The binding affinity and specificity of the aptamer are high. Aptamers are taken from records of nucleic acids by frequent rounds of the assortment and an amplification procedure recognized as the in vitro genetic selection strategy. This method was established more than two decades ago and diverse aptamers were chosen in opposition to a broad variety of targets, together with small molecules, simple ions, peptides, organelles, proteins, and viruses (Gold et al. 1995; Osborne and Ellington 1997; Wilson and Szostak 1999; Cho et al. 2009). The binding specificity and affinity of aptamer were achieved against the associated target, which was corresponding or exceeded the affinity achieved between antigens and antibodies. Furthermore, in contrast to antibodies, aptamers are small in size and easier to produce. Besides, many modifications were able to integrate, and these also did not have immunogenicity and toxicity. Due to these compensations, aptamers have been used in many applications, including diagnostics, imaging, and therapeutic purposes, Gopinath et al. (2008), studied another aptamer assortment method of influenza type A virus (H3N2). They incorporated entire H3N2 cells as targets and aptamers were selected, which specifically bind to the HA protein present on the virus surface. The affinity among HA proteins and aptamers was 15-fold greater than the affinity among HA protein and monoclonal antibodies. Moreover, the determination and detection of influenza virus, aptamers have another advantage, that it is stated as a trustable contestant for prophylaxis and treatment of influenza virus infections. An example of this advantage is DNA aptamers, which exclusively target the H3N2 influenza virus, and their antiviral activity in vitro was also described. These aptamers were thought to destroy virus entry, and thus decrease the infection procedure speed so that the immune system of the host has instance to react to infection (Gopinath et al. 2008; Anthony et al. 2010; Dougherty et al. 2015). Many sensors are developed for the detection of H3N2 using different methodologies. The same principles are also followed by SARS-CoV-2 detection quickly. These H3N2 biosensors can be classified into the following subclasses:

\section{Optical immunosensor}

A waveguide sensor was fabricated to detect the Influenza $\mathrm{A}(\mathrm{H} 3 \mathrm{~N} 2)$ virus. Gold nanoparticles (AuNPs) were used to increase the signal, which is thought to be a striking tool for bio-nano sensor fabrication and absorb visible light at 


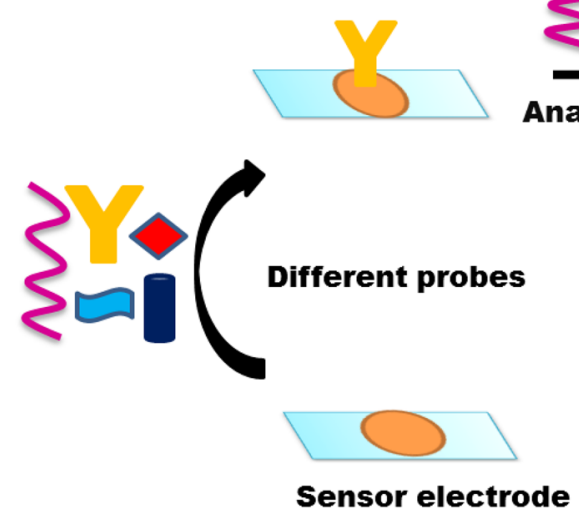

Sensor electrode
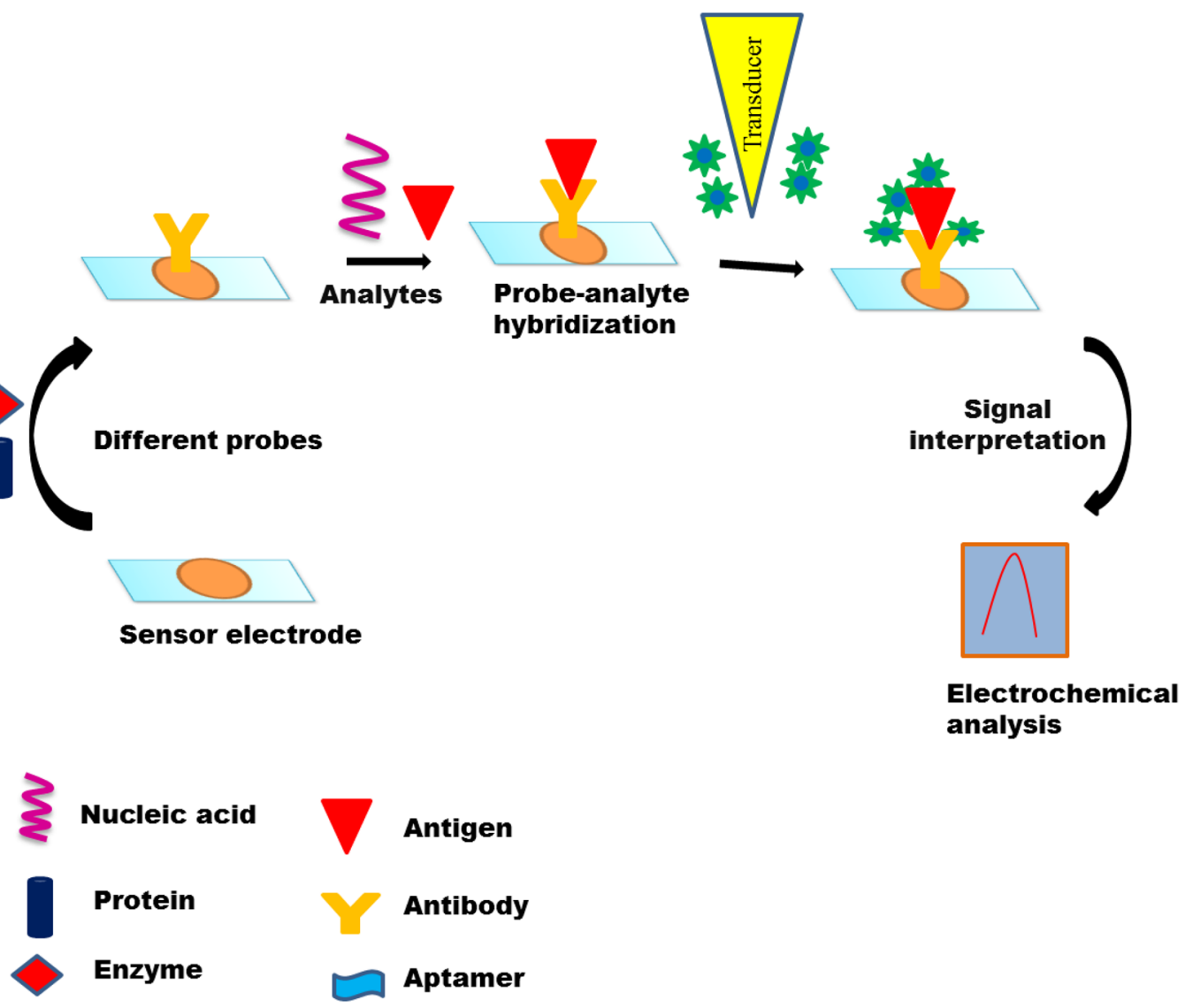

Fig. 3 The basic design of biosensor showing a probe will bind only with a specific analyte and transducer will convert biological reactions to interpretable signals

$520 \mathrm{~nm}$, because of plasmons excitation (Nagel et al. 2011; Tinguely et al. 2011). To detect the virus, AuNP- conjugated anti-A/Udorn/307/1972 antibody was used together with a silicon-based sensing plate operating in a waveguide manner to identify the Influenza A(H3N2) virus (A/Udorn/307/1972 and A/Brisbane/10/2007) (Gopinath et al. 2013). An optical system with Surface plasmon excitation was used to develop a sensor with a self-assembled monolayer with $-\mathrm{COOH}$ group combined with anti-HA antibodies against the H3N2 virus for better sensitivity and higher intense fluorescence using a prism-shaped fluidic channel to get optimum incident light. It can detect $0.2 \mathrm{HAunits}^{-1}$ of the influenza virus in 1-2 $\mu 1$ of the sample (Nomura et al. 2013).

\section{Impedimetric biosensor}

A glycan-based impedimetric biosensor was fabricated for detecting Influenza A(H3N2) virus particles. Glycans are composite carbohydrates, implicated in a lot of physiological and pathological processes, such as immune response, tumor metastasis, molecular recognition, inflammation, and cell signaling, in living organisms infected by bacteria/viruses (Cecioni et al. 2015; Pritchard et al. 2015; Cao-Milan and Liz-Marzan 2014; Rogowski et al. 2016). Various authors fabricated glycan-based biosensors (Cui et al. 2017) because these are ordinary viral receptors with a specific selectivity for pathogenic subtypes. This impedimetric sensor was fabricated by immobilizing glycan on a self-assembled monolayer composed of OEG-COOH (oligoethylene glycol). These simple modifications help in reducing the cost and time for detecting the virus and make it a cost-effective method as compared to costly antibodies with LOD 13 viral particles per $1 \mu \mathrm{L}$ level (Hushegyi et al. 2016).

A boron-doped diamond sensor was prepared using a diamond electrode, which was functionalized with polyclonal anti-M1 antibodies to recognize the common biomarker for the influenza virus, M1 protein. A change in impedance spectra happened after the incorporation of the M1 protein with anti-M1 sites of the electrode. A LOD of $1 \mathrm{fg} / \mathrm{ml}$ in saliva buffer was achieved for the M1 biomarker, which corresponds to 5-10 viruses for each sample in 5 min (Nidzworski et al. 2017). 


\section{QCM immunosensor}

The quartz crystal microbalance (QCM) was employed to develop immunosensor for influenza virus detection (Sasaki et al. 2007; Hewaet al. 2009; Owen et al. 2007). Several attempts were made for the detection of influenza antibodies and then individual differences were found in the process of attaching the electrode surface. A crystal surface was used instead of gold nanoparticles (AuNPs) for the detection of influenza A virus (VR-544, H3N2), which was based on the attachment of viral antigen and polyclonal $\mathrm{IgG}$ antibodies in opposition to the antigen. Conversely, determination through AuNPs was carried out because of the growing sensitivity of the QCM immunosensor for the influenza virus recognition. These methods were applied to three types of influenza viruses H3N2, H5N1, and H1N1 (Hewa et al. 2009).

\section{SERS immunosensor}

In 2017, a SERS immunosensor was developed based on surface-enhanced Raman scattering (SERS) spectroscopy for the detection of inactivated Influenza $\mathrm{A}(\mathrm{H} 3 \mathrm{~N} 2)$ virus (A/Shanghai/4084 T/2012) by making a sandwich complex consisting of SERS tags, target influenza viruses, and highly SERS-active magnetic supporting substrates. This substrate allowed the enrichment and separation of viruses from a complex matrix. With a portable Raman spectrometer, the immunosensor could detect H3N2 down to $10^{2}$ TCID $50 / \mathrm{mL}$ with a good linear relationship from $10^{2}$ to $5 \times 10^{3}$ TCID50/ $\mathrm{mL}$ (Sun et al. 2017).

\section{GMR-based biosensor}

A Giant magneto-resistance (GMR)-based biosensor was developed using monoclonal antibodies of nucleoprotein (vNP) in amalgamation with magnetic nanoparticles (MNPs). The existence of the influenza virus allowed the binding of MNPs to the GMR sensor. This binding was proportional to the concentration of the virus. MNPs do not bleach, no ferromagnetism property in biological samples (Krishna et al. 2016). Using swine influenza virus H3N2v as a representative virus, the limit of detection (LOD) of GMR biosensor assay was $1.5 \times 10^{2} \mathrm{TCID}_{50} / \mathrm{mL}$ virus. A comparison of GMR biosensor with ELISA proved that GMR biosensor was more sensitive than ELISA (Zhang et al. 2014).

\section{Aptamer-based biosensor}

A surface-enhanced Raman scattering-based aptamer sensor was developed for $\mathrm{H} 3 \mathrm{~N} 2$ virus detection. The primary aptamers and secondary aptamer were created specifically for the hemagglutinin of the $\mathrm{H} 3 \mathrm{~N} 2$ virus. $\mathrm{SiO}_{2}$-covered silicon plate with silver zones was used for this test. The primary aptamer was attached with metal nanoparticles of the sensor followed by virus binding and then secondary aptamer. High sensitivity with high specificity was obtained for influenza strains with a LOD of $10^{4}$ virus particles per sample (Kukushkin et al. 2019).

\section{Plasmonic contrast imaging biosensor}

A plasmonic contrast imaging biosensor was also prepared based on the measurement of the intensity differentiation among the $p$ - and $s$-polarization images at plasmonic excitation. At plasmonic resonance, only the $p$-polarization light is excited, while $s$-polarization light remains the same. Image intensity subtraction amid both polarizations can abolish general system noise and enhance sensor resolution. In refractive index measurements, the sensor resolution was found to be $4.36 \times 10^{-7} \mathrm{RIU}$. The plasmonic contrast imaging sensor has been demonstrated for H3N2 influenza antibody detection and DNA-DNA molecular binding detections. The detection limit was found to be $8.6 \mathrm{nM}\left(320 \mathrm{ng} \mathrm{mL}^{-1}\right)$ for Influenza $\mathrm{A}(\mathrm{H} 3 \mathrm{~N} 2)$ virus antibodies. The sensor resolution for DNA molecule detection was $38 \mathrm{nM}$ (Wong et al. 2019).

\section{Localized surface plasmon resonance (LSPR)-based fluorescent nanosensor}

This biosensor was developed using quantum dots (CdSeTeS) conjugated with anti-hemagglutinin antibody (anti-HA Ab) simultaneously with gold nanoparticles thiolated with L-cysteine which are conjugated with antineuraminidase antibodies. Both antigens are targeted in this work using a separate binding agent like AuNPs and quantum dots. When antigen interacts with antibody, localized surface plasmon resonance will generate from gold nanoparticles which enhance the immune-fluorescence signal of alloyed $\mathrm{CdSeTeS}$ quantum dots. Using quantum dots along with AuNPs increases the fluorescent signal and sensitivity of the sensor for the concentration of the sample. The sensor has a limit of detection of $10 \mathrm{PFU} / \mathrm{mL}$ for clinically isolated Influenza A(H3N2) virus (Takemura et al. 2017).

\section{Conclusion and future perspective}

Since the introduction of Influenza A(H3N2) virus in 1968, a lot of antigenic changes have happened in the virus. It has added numerous N-linked glycans to the surface of HA protein and has increased the overall net charge of the HA molecule, changed their preferences in receptor-binding, and altered the ability of neuraminidase (NA) to agglutinate red blood cells before host entry (Allen and Ross 2018). The mutations were also reported in viruses, such as N158-linked glycosylation in HA, HA F193S substitution, HA T135K, and/or I192T, which rapidly alters the genotype/phenotype

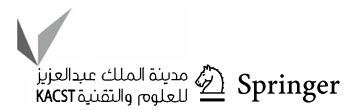


Table 1 A comparison of all analytical methods for detection of the Influenza A(H3N2) virus is explained in the table

\begin{tabular}{|c|c|c|c|c|c|c|c|}
\hline S.N & Detection method & Target & Time & L.O.D & Specificity & Sensitivity & References \\
\hline 1 & $\begin{array}{l}\text { Minor groove binder } \\
\text { TaqMan assay }\end{array}$ & HA gene & - & $\begin{array}{l}16.5 \text { standard DNA } \\
\text { copies }\end{array}$ & - & - & (Wang et al. 2011) \\
\hline 2 & $\begin{array}{l}\text { Waveguide-mode } \\
\text { sensor }\end{array}$ & HA antigen & - & 86,103 PFU/ml & - & - & (Gopinath et al. 2013) \\
\hline 3 & Optical biosensor & Virus & - & $0.2 \mathrm{HAU} / \mathrm{ml}$ & - & - & (Nomura et al. 2013) \\
\hline 4 & $\begin{array}{l}\text { Europium nanoparti- } \\
\text { cle-based immuno- } \\
\text { assay }\end{array}$ & Nucleoprotein & - & $1.00 \times 10^{2.0} \mathrm{EID}_{50} / \mathrm{ml}$ & $100 \%$ & $90.7 \%$ & (Zhang et al. 2014) \\
\hline 5 & RT-PCR & Viral RNA & $20-30 \mathrm{~min}$ & - & $>95 \%$ & $100 \%$ & (Cui et al. 2016) \\
\hline 6 & GMR biosensor & Nucleoprotein (NP) & - & $1.5 \times 10^{2} \mathrm{TCID} 50 / \mathrm{mL}$ & - & - & (Krishna et al. 2016) \\
\hline 7 & Glycan based biosensor & Lectin & - & 13 viral particles/ $\mu \mathrm{l}$ & - & - & (Hushegyi et al. 2016) \\
\hline 8 & $\begin{array}{l}\text { Multiplex one-step } \\
\text { real-time RT-PCR } \\
\text { assay }\end{array}$ & HAgene & - & $\begin{array}{l}4.8 \times 10^{1} \text { copies per } \\
\text { reaction }\end{array}$ & $>95 \%$ & $100 \%$ & (Cui et al. 2016) \\
\hline 9 & LSPR nanosensor & HA, NA antibody & - & $10 \mathrm{PFU} / \mathrm{mL}$ & - & - & (Takemura et al. 2017) \\
\hline 10 & SERS immunosensor & Whole virus & - & $10^{2} \mathrm{TCID}_{50} / \mathrm{mL}$ & - & - & (Sun et al. 2017) \\
\hline 11 & $\begin{array}{l}\text { Multiplex RT-PCR } \\
\text { assay }\end{array}$ & NP protein & - & $1 \times 10^{0} \mathrm{TCID}_{50} / 100 \mu \mathrm{l}$ & - & - & (Wang et al. 2017) \\
\hline 12 & $\begin{array}{l}\text { Antibody modified } \\
\text { boron-doped dia- } \\
\text { mond }\end{array}$ & Anti-M1 antibodies & - & $1 \mathrm{fg} / \mathrm{ml}$ & - & - & (Nidzworski et al. 2017) \\
\hline 13 & DFA & Viral antigen & $2-4 \mathrm{~h}$ & - & $80-100 \%$ & $70-100 \%$ & (Dziąbowska et al. 2018) \\
\hline 14 & LAMP & Viral RNA & $2 \mathrm{~h}$ & - & $100 \%$ & $97.8 \%$ & (Dziąbowska et al. 2018) \\
\hline 15 & SERS aptasensor & $\begin{array}{l}\text { HA protein of whole } \\
\text { virus }\end{array}$ & $12 \mathrm{~min}$ & $\begin{array}{l}10^{4} \text { virus particles per } \\
\text { sample }\end{array}$ & - & - & (Kukushkin et al. 2019) \\
\hline
\end{tabular}

All methods detect a different analyte of the same virus at a different detection time with a limit of detection value

$D F A$ direct fluorescent antibody, GMR giant magneto-resistance, LAMP loop-mediated isothermal amplification-based assay, LSPR localized surface plasmon resonance, SERS surface-enhanced Raman scattering

of the virus. Different simulations are used for the early prediction of virus mutations. Antigenic drift in 3C.3a clades which is currently circulating reported vaccine ineffectiveness in people and making them vulnerable against the virus. A study about vaccine effectiveness was performed with Influenza A(H3N2) virus patients of the 2018-2019 influenza seasons in the U.S.A (Castro et al. 2020). The Reverse Transcriptase polymerase chain reaction (PCR) was used for testing samples, and the hemagglutinin gene segment was sequenced for genetic analysis. There is a decrease in the effectiveness of vaccines on current patients due to antigenic drift in the Influenza A(H3N2) virus of 3C.3a clade which is circulating currently and suggesting an update in vaccine components. In a study, phylodynamic simulations were used to predict in advance the future virus strains that will dominate on earth. These types of studies help in making vaccines production fast without wasting time in strain selection (Flannery et al. 2020). So, diagnostic methods have to be modified according to the new assorted or mutated virus for detection. All the methods reported in the review have different sensitivity and specificity as mentioned in Table 1 .
Old methods are time-consuming and laborious, and some of them are infectious too. Whereas biosensors are providing fast results, good sensitivity, specificity, and are easy to perform. Thus, with changing virus detection methods, the biosensors are also evolving to catch the virus at the earliest to save human life and global economic burden due to pathogenic infections. As these viruses evolve and change their receptor-binding ability, specificities, charge at proteins, virulence, and resistance against human immunity, it becomes essential to make a joint effort by collaborating with multiple disciplines of science to study the changed behavior of the virus.

Acknowledgments One of the authors (Ravina) wishes to acknowledge the award of senior research fellowship (SRF) of Indian Council of Medical Research (ICMR), New Delhi during the tenure of this work.

\section{Compliance with ethical standards}

Conflict of interest The authors have no conflict of interest. 


\section{References}

Ahmed SR, Kim J, Suzuki T, Lee J, Park EY (2016) Detection of influenza virus using peroxidase-mimic of gold nanoparticles. Biotechnol Bioeng 113:2298-2303. https://doi.org/10.1002/bit.25982

Allen JD, Ross TM (2018) H3N2 influenza viruses in humans: viral mechanisms, evolution, and evaluation. Hum Vaccin Immun Other 14:1840-1847. https://doi.org/10.1080/21645515.2018.1462639

Anthony DK, Supriya P, Andrew E (2010) Aptamer as therapeutics. Nat Rev Drug Discov. 9:537-530. https://doi.org/10.1038/nrd3141

Barbé F, Labarque G, Pensaert M, Van Reeth K (2009) Performance of a commercial Swine influenza virus $\mathrm{H} 1 \mathrm{~N} 1$ and $\mathrm{H} 3 \mathrm{~N} 2$ antibody enzyme-linked immunosorbent assay in pigs experimentally infected with European influenza viruses. J Vet Diagn Investig. 21:88-96. https://doi.org/10.1177/104063870902100113

Barr IG, McCauley J, Cox N, Daniels R, Engelhardt OG, Fukuda K, Grohmann G, Hay A, Kelso A, Klimov A, Odagiri T (2010) Epidemiological, antigenic and genetic characteristics of seasonal influenza A (H1N1), A (H3N2) and B influenza viruses: basis for the WHO recommendation on the composition of influenza vaccines for use in the 2009-2010 Northern Hemisphere season. Vaccine 28:1156-1167. https://doi.org/10.1016/j.vaccine.2009.11.043

Blackburne BP, Hay AJ, Goldstein RA (2008) Changing selective pressure during antigenic changes in human influenza H3. PLoS Pathog. 4:e1000058. https://doi.org/10.1371/journal.ppat.1000058

Cao-Milan R, Liz-Marzan LM (2014) Gold nanoparticle conjugates: recent advances toward clinical applications. Expert Opin Drug Deliv 11:741-752. https://doi.org/10.1039/C2CS35427F

Castro LA, Bedford T, Meyers LA (2020) Early prediction of antigenic transitions for influenza A/H3N2. PLOS ComputBiol 16:e1007683. https://doi.org/10.1371/journal.pcbi.1007683

Cecioni S, Imberty A, Vidal S (2015) Glycomimetics versus multivalent glycoconjugates for the design of high affinity lectin ligands. Chem Rev 115:525-561. https://doi.org/10.1021/cr500303t

Chambers BS, Li Y, Hodinka RL, Hensley SE (2014) Recent H3N2 influenza virus clinical isolates rapidly acquire hemagglutinin or neuraminidase mutations when propagated for antigenic analyses. J Virol 88:10986-10989. https://doi.org/10.1128/JVI.01077-14

Chauhan N, Narang J, Pundir S, Singh S, Pundir CS (2013) Laboratory diagnosis of swine flu: a review. Artif Cells Nanomed Biotechnol. 41:189-195. https://doi.org/10.3109/10731199.2012.716063

Cho EJ, Lee JW, Ellington AD (2009) Applications of aptamers as sensors. Annu Rev Anal Chem 2:241-264. https://doi.org/10.1146/ annurev.anchem.1.031207.112851

Cui D, Zhao D, Xie G, Yang X, Huo Z, Zheng S, Yu F, Chen Y (2016) Simultaneous detection of influenza A subtypes of H3N2 virus, pandemic (H1N1) 2009 virus and reassortant avian H7N9 virus in humans by multiplex one-step real-time RT-PCR assay. Springerplus 5:4-11. https://doi.org/10.1186/s40064-016-3733-9

Cui X, Das A, Dhawane AN, Sweeney J, Zhang X, Chivukula V, Iyer SS (2017) Highly specific and rapid glycan based amperometric detection of influenza viruses. ChemSci 8:3628-3634. https://doi. org/10.1039/c6sc03720h

Dougherty C, Cai W, Hong H (2015) Applications of aptamers in targeted imaging: state of the art. Curr Top Med Chem 15:11381152. https://doi.org/10.2174/1568026615666150413153400

Dziąbowska K, Czaczyk E, Nidzworski D (2018) Detection methods of human and animal influenza virus-current trends. Biosensors 8:94. https://doi.org/10.3390/bios8040094

Flannery B, Kondor RJG, Chung JR, Gaglani M, Reis M, Zimmerman RK, Nowalk MP, Jackson ML, Jackson LA, Monto AS, Martin ET (2020) Spread of antigenically drifted influenza A (H3N2) viruses and vaccine effectiveness in the United States during the 2018-2019 season. J Infect Dis 221:8-15. https://doi.org/10.1093/ infdis/jiz543
Gavin PJ, Thomson RB Jr (2004) Review of rapid diagnostic tests for influenza. Clin Appl Immunol Rev 4:151-172. https://doi. org/10.1016/S1529-1049(03)00064-3

Gold L, Polisky B, Uhlenbeck O, Yarus M (1995) Diversity of oligonucleotide functions. Annu Rev Biochem 64:763-797. https://doi. org/10.1146/annurev.bi.64.070195.003555

Gopinath SC, Awazu K, Fujimaki M, Shimizu K (2013) Evaluation of anti-A/Udorn/307/1972 antibody specificity to influenza A/ H3N2 viruses using an evanescent-field coupled waveguidemode sensor. PLoS ONE 8:e81396. https://doi.org/10.1371/journ al.pone. 0081396

Gopinath SC, Misono TS, Kumar PK (2008) Prospects of ligandinduced aptamers. Crit Rev Anal Chem. 38:34-47. https://doi. org/10.1080/10408340701804558

Gulati S, Smith DF, Cummings RD, Couch RB, Griesemer SB, George KS, Webster RG, Air GM (2013) Human H3N2 influenza viruses isolated from 1968 to 2012 show varying preference for receptor substructures with no apparent consequences for disease or spread. PLoS ONE 8:e66325. https://doi.org/10.1371/journ al.pone. 0066325

Hewa TMP, Tannock GA, Mainwaring DE, Harrison S, Fecondo JV (2009a) The detection of influenza A and B viruses in clinical specimens using a quartz crystal microbalance. J Virol Methods 162:14-21. https://doi.org/10.1016/j.jviromet.2009.07.001

Hewa TMP, Tannock GA, Mainwaring DE, Harrison S, Fecondo JV (2009b) Virol. Methods 162(14): 107

https://www.cdc.gov/flu/about/viruses/types.html. Accessed on 1 Jan 2020.

https://www.cdc.gov/flu/spotlights/2018-2019/new-lab-method-test-flu. html.. Accessed on 16 Apr 2020.

https://www.who.int/docs/default-source/coronaviruse/real-time-rtpcr-assays-for-the-detection-of-sars-cov-2-institut-pasteur-paris .pdf?sfvrsn=3662fcb6_2. Accessed on 18 Oct 2020.

Hushegyi A, Pihíková D, Bertok T, Adam V, Kizek R, Tkac J (2016) Ultrasensitive detection of influenza viruses with a glycan-based impedimetric biosensor. Biosens Bioelectron 79:644-649. https ://doi.org/10.1016/j.bios.2015.12.102

Influenza signs and symptoms and the role of laboratory diagnostics, seasonal influenza (Flu) CDC. Available on https://www.cdc.gov/ flu/professionals/diagnosis/labrolesprocedures.htm.. Accessed on 6 Sep 2018

Influenza signs and symptoms and the role of laboratory diagnosticslseasonal influenza (Flu)|CDC. Accessed on 15 May 2020

Influenza update 362, 2020. https://www.who.int/influenza/surve illance_monitoring/updates/latest_update_GIP_surveillance/en/. Accessed on 2 Mar 2020

Jang S, Choi H, Jung Y, Moon E, Yoon T (2016) A Comparison of $\mathrm{H} 1 \mathrm{~N} 1$ and $\mathrm{H} 3 \mathrm{~N} 2$ viruses using decision tree and apriori algorithm. Int J Mach Learn Cyb 6(1):76. https://doi.org/10.18178/ ijmlc.2016.6.1.576

Jorquera PA, Mishin VP, Chesnokov A, Nguyen HT, Mann B, Garten R, Barnes J, Hodges E, De La Cruz J, Xu X, Katz J (2019) Insights into the antigenic advancement of influenza A (H3N2) viruses 2011-2018. Sci Rep 9:1-16. https://doi.org/10.1038/s4159 8-019-39276-1

Kaji M, Watanabe A, Aizawa H (2003) Differences in clinical features between influenza A H1N1, A H3N2, and B in adult patients. Respirology 8(2):231-233. https://doi.org/10.104 6/j.1440-1843.2003.00457.x

Kim HK, Oh SH, Yun KA, Sung H, Kim MN (2013) Comparison of Anyplex II RV16 with the xTAG respiratory viral panel and Seeplex RV15 fordetection of respiratory viruses. J Clin Microbiol 51:1137-1141. https://doi.org/10.1128/JCM.02958-12

Koski RR, Klepser ME (2017) A systematic review of rapid diagnostic tests for influenza: considerations for the

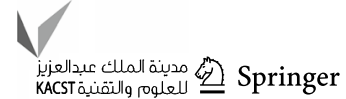


community pharmacist. J Am Pharm Assoc 57:13-19. https:// doi.org/10.1016/j.japh.2016.08.018

Krejcova L, Hynek D, Adam V, Hubalek J, Kizek R (2012) Electrochemical sensors and biosensors for influenza detection. Int $\mathrm{J}$ Electrochem Sci 7:10779-10801

Krishna VD, Wu K, Perez AM, Wang JP (2016) Giant magnetoresistance-based biosensor for detection of influenza A virus. Front Microbiol 7:400. https://doi.org/10.3389/fmicb.2016.00400

Kukushkin VI, Ivanov NM, Novoseltseva AA, Gambaryan AS, Yaminsky IV, Kopylov AM, Zavyalova EG (2019) Highly sensitive detection of influenza virus with SERS aptasensor. PLoS ONE 14:e0216247. https://doi.org/10.1371/journal.pone.0216247

Kumar N, Bhatia S, Pateriya AK, Sood R, Nagarajan S, Murugkar HV, Kumar S, Singh P, Singh VP (2020) Label-free peptide nucleic acid biosensor for visual detection of multiple strains of influenza A virus suitable for field applications. Anal Chim Acta 1093:123130. https://doi.org/10.1016/j.aca.2019.09.060

Le TT, Chang P, Benton DJ, McCauley JW, Iqbal M, Cass AE (2017) Dual recognition element lateral flow assay toward multiplex strain specific influenza virus detection. Anal Chem 89(12):67816786. https://doi.org/10.1021/acs.analchem.7b01149

Lednicky JA, Loeb JC (2013) Detection and isolation of airborne influenza A H3N2 virus using a Sioutas personal cascade impactor sampler. Influenza Res Treat 2013:656825. https://doi. org/10.1155/2013/656825

Lee MS, Chang PC, Shien JH, Cheng MC, Shieh HK (2001) Identification and subtyping of avian influenza viruses by reverse transcription-PCR. J Virol Methods 97:13-22. https://doi.org/10.1016/ S0166-0934(01)00301-9

Leirs K, Tewari KP, Decrop D, Pérez-Ruiz E, Leblebici P, Van Kelst B, Compernolle G, Meeuws H, Van Wesenbeeck L, Lagatie O, Stuyver L (2016) Bioassay development for ultrasensitive detection of influenza a nucleoprotein using digital ELISA. Anal Chem 88:8450-8458. https://doi.org/10.1021/acs.analchem.6b00502

Li ZN, Weber KM, Limmer RA, Horne BJ, Stevens J, Schwerzmann J, Wrammert J, McCausland M, Phipps AJ, Hancock K, Jernigan DB (2017) Evaluation of multiplex assay platforms for detection of influenza hemagglutinin subtype specific antibody responses. J Virol Methods 243:61-67. https://doi.org/10.1016/j.jviro met.2017.01.008

Lin C, Guo Y, Zhao M, Sun M, Luo F, Guo L, Qiu B, Lin Z, Chen G (2017) Highly sensitive colorimetric immunosensor for influenza virus H5N1 based on enzyme-encapsulated liposome. Anal ChimActa 963:112-118. https://doi.org/10.1016/j.aca.2017.01.031

Lin Y, Wharton SA, Whittaker L, Dai M, Ermetal B, Lo J, Pontoriero A, Baumeister E, Daniels RS, Mccauley JW (2017) The characteristics and antigenic properties of recently emerged subclade 3C.3a and 3C.2a human influenza A (H3N2) viruses passaged in MDCK cells. Influenza Other Respir Viruses 11:263-274. https ://doi.org/10.1111/irv.12447

Lin YP, Xiong WSA, Martin SR, Coombs PJ, Vachieri SG, Christodoulou E, Walker PA, Liu J, Skehel JJ, Gamblin SJ (2012) Evolution of the receptor binding properties of the influenza A (H3N2) hemagglutinin. Proc Natl Acad Sci 109:21474-21479. https://doi. org/10.1073/pnas.1218841110

Matrosovich M, Matrosovich T, Carr J, Roberts NA, Klenk HD (2003) Overexpression of the $\alpha$-2, 6-sialyltransferase in MDCK cells increases influenza virus sensitivity to neuraminidase inhibitors. J Virol. 77:8418-8425. https://doi.org/10.1128/ JVI.77.15.8418-8425.2003

McMullen AR, Anderson NW, Burnham CAD, Education Committee of the Academy of Clinical Laboratory Physicians and Scientists (2016) Pathology consultation on influenza diagnostics. Am J ClinPathol 145(440):448. https://doi.org/10.1093/AJCP/AQW039

Medeiros R, Escriou N, Naffakh N, Manuguerra JC, van der Werf S (2001) Hemagglutinin residues of recent human A (H3N2) influenza viruses that contribute to the inability to agglutinate chicken erythrocytes. Virology 289:74-85. https://doi. org/10.1006/viro.2001.1121

Nagel J, Chunsod P, Zimmerer C, Simon F, Janke A, Heinrich G (2011) Immobilization of gold nanoparticles on a polycarbonate surface layer during molding. Mater ChemPhys 129:99-604. https://doi.org/10.1016/j.matchemphys.2011.04.069

Nidzworski D, Siuzdak K, Niedziałkowski P, Bogdanowicz R, Sobaszek M, Ryl J, Weiher P, Sawczak M, Wnuk E, Goddard WA, Jaramillo-Botero A (2017) A rapid-response ultrasensitive biosensor for influenza virus detection using antibody modified boron-doped diamond. Sci Rep 7:1-10. https://doi.org/10.1038/ s41598-017-15806-7

Nomura KI, Gopinath SC, Lakshmipriya T, Fukuda N, Wang X, Fujimaki M (2013) An angular fluidic channel for prism-free surface-plasmon-assisted fluorescence capturing. Nat Commun 4:1-7. https://doi.org/10.1038/ncomms3855

Notomi T, Okayama H, Masubuchi H, Yonekawa T, Watanabe K, Amino N, Hase T (2000) Loop-mediated isothermal amplification of DNA. Nucleic Acids Res 28:e63-e63. https://doi. org/10.1093/nar/28.12.e63

Oh DY, Barr IG, Mosse JA, Laurie KL (2008) MDCK-SIAT1 cells show improved isolation rates for recent human influenza viruses compared to conventional MDCK cells. J Clin Microbiol 46:2189-2194. https://doi.org/10.1128/JCM.00398-08

Osborne SE, Ellington AD (1997) Nucleic acid selection and the challenge of combinatorial chemistry. Chem Rev 97:349-370. https://doi.org/10.1021/cr960009c

Owen TW, Al-Kaysi RO, Bardeen CJ, Cheng Q (2007) Sens Actuator B Chem 126:691

Parker L, Wharton SA, Martin SR, Cross K, Lin Y, Liu Y, Feizi T, Daniels RS, McCauley JW (2016) Effects of egg-adaptation on receptor-binding and antigenic properties of recent influenza A (H3N2) vaccine viruses. J Gen Virol 97:1333-1344. https://doi. org/10.1099/jgv.0.000457

Pavlova S, D'Alessio F, Houard S, Remarque EJ, Stockhofe N, Engelhardt OG (2017) Workshop report: Immunoassay standardisation for "universal" influenza vaccines. Influenza Other Respir Viruses 11(194-201):1. https://doi.org/10.1111/irv.12445

Peng W, de Vries RP, Grant OC, Thompson AJ, McBride R, Tsogtbaatar B, Lee PS, Razi N, Wilson IA, Woods RJ, Paulson JC (2017) Recent H3N2 viruses have evolved specificity for extended, branched human-type receptors, conferring potential for increased avidity. Cell Host Microbe 21:23-34. https://doi. org/10.1016/j.chom.2016.11.004

Poon LL, Leung CS, Chan KH, Lee JH, Yuen KY, Guan Y, Peiris JS (2005) Detection of human influenza A viruses by loop-mediated isothermal amplification. J Clin Microbiol 43:427-430. https://doi.org/10.1128/JCM.43.1.427

Poon LL, Leung CS, Tashiro M, Chan KH, Wong BW, Yuen KY, Peiris GY, JS, (2004) Rapid detection of the severe acute respiratory syndrome (SARS) coronavirus by a loop-mediated isothermal amplification assay. Clin Chem 50(6):1050-1052. https ://doi.org/10.1373/clinchem.2004.032011

Pritchard LK, Spencer DI, Royle L, Bonomelli C, Seabright GE, Behrens AJ, Kulp DW, Menis S, Krumm SA, Dunlop DC, Crispin DJ (2015) Glycan clustering stabilizes the mannose patch of HIV-1 and preserves vulnerability to broadly neutralizing antibodies. Nat Commun 6:1-11. https://doi.org/10.1038/ ncomms 8479

Ravina, Dalal A, Mohan H, Prasad M, Pundir CS (2020) Detection methods for influenza A H1N1 virus with special reference to biosensors: a review. Biosci Rep 40(2):BSR20193852. https://doi. org/10.1042/BSR20193852

Ravina, Mohan H, Gill PS, Kumar A (2019) Hemagglutinin genebased biosensor for early detection of swine flu (H1N1) 
infection in human. Int J Biol Macromol 130:720-726. https:// doi.org/10.1016/j.ijbiomac.2019.02.149

Rogowski A, Briggs JA, Mortimer JC, Tryfona T, Terrapon N, Lowe EC, Baslé A, Morland C, Day AM, Zheng H, Rogers TE (2016) Corrigendum: glycan complexity dictates microbial resource allocation in the large intestine. Nat Commun 7:1-16. https://doi. org/10.1038/ncomms 10705

Ruscito A, DeRosa MC (2016) Small-molecule binding aptamers: selection strategies, characterization, and applications. Front Chem 4:14. https://doi.org/10.3389/fchem.2016.00014

Sasaki M, Choi Sang G, Li Z, Ikeura R, Kim H, Xue F (2007) (Editors), ICMIT 2007: mechatronics, Mems, and Smart Materials, Pts 1 and 2. Spie Int Soc Optical Engineering, Bellingham 2008:P7943

Shim JM, Kim J, Tenson T, Min JY, Kainov DEV (2017) Counterresponse, influenza virus infection, interferon response, viral counter-response, and apoptosis. Viruses 9:223. https://doi. org/10.3390/v9080223

Stöhr K (2002) Influenza-WHO cares. Lancet Infect Dis 517:9. https ://doi.org/10.1016/S1473-3099(02)00366-3

Sueki A, Matsuda K, Yamaguchi A, Uehara M, Sugano M, Uehara T, Honda T (2016) Evaluation of saliva as diagnostic materials for influenza virus infection by PCR-based assays. Clin Chim Acta 453:71-74. https://doi.org/10.1016/j.cca.2015.12.006

Sun Y, Xu L, Zhang F, Song Z, Hu Y, Ji Y, Shen J, Li B, Lu H, Yang H (2017) A promising magnetic SERS immunosensor for sensitive detection of avian influenza virus. Biosens Bioelectron 89:906912. https://doi.org/10.1016/j.bios.2016.09.100

Takemura K, Adegoke O, Takahashi N, Kato T, Li TC, Kitamoto N, Tanaka T, Suzuki T, Park EY (2017) Versatility of a localized surface plasmon resonance-based gold nanoparticle-alloyed quantum dot nanobiosensor for immunofluorescence detection of viruses. Biosens Bioelectron 89:998-1005. https://doi.org/10.1016/j. bios.2016.10.045

Thi VLD, Herbst K, Boerner K, Meurer M, Kremer LP, Kirrmaier D, Freistaedter A, Papagiannidis D, Galmozzi C, Boulant SML, S, (2020) A colorimetric RT-LAMP assay and LAMP-sequencing for detecting SARS-CoV-2 RNA in clinical samples. Sci Transl Med 12(556):7075. https://doi.org/10.1126/scitranslmed.abc7075

Tinguely JC, Sow I, Leiner C, Grand J, Hohenau A, Felidj N, Aubard J, Krenn JR (2011) Gold nanoparticles for plasmonicbiosensing: the role of metal crystallinity and nanoscale roughness. Bio NanoSci 1:128-135. https://doi.org/10.1007/s12668-011-0015-4

Treanor JJ, Schiff GM, Couch RB, Cate TR, Brady RC, Hay CM, Wolff M, She D, Cox MM (2006) Dose-related safety and immunogenicity of a trivalent baculovirus-expressed influenza-virus hemagglutinin vaccine in elderly adults. J Infect Dis. 193:1223-1228. https://www.jstor.org/stable/30086531

Ushirogawa H, Naito T, Tokunaga H, Tanaka T, Nakano T, Terada K (2016) Re-emergence of H3N2 strains carrying potential neutralizing mutations at the $\mathrm{N}$-linked glycosylation site at the hemagglutinin head, post the $2009 \mathrm{H} 1 \mathrm{~N} 1$ pandemic. BMC Infect Dis 16:380. https://doi.org/10.1186/s12879-016-1738-1

Van Baalen CA, Els C, Sprong L, Van Beek R, Van der Vries E, Osterhaus ADME, Rimmelzwaan GF (2014) Detection of nonhemagglutinating influenza a (h3) viruses by enzyme-linked immunosorbent assay in quantitative influenza virus culture. J Clin Microbiol 52:1672-1677. https://doi.org/10.1128/JCM.03575-13

Vemula SV, Zhao J, Liu J, Xue XW, Biswas HSI (2016) Current approaches for diagnosis of influenza virus infections in humans. Viruses 8:1-15. https://doi.org/10.3390/v8040096

Wang B, Russell ML, Brewer A, Newton J, Singh P, Ward BJ, Loeb M (2017) Single radial haemolysis compared to haemagglutinin inhibition and microneutralization as a correlate of protection against influenza A H3N2 in children and adolescents. Influenza Other Respir Viruses 11:283-288. https://doi.org/10.1111/irv.12450

Wang C, Wang Q, Hu J, Sun H, Pu J, Liu J, Sun Y (2017) A multiplex RT-PCR assay for detection and differentiation of avian-origin Canine $\mathrm{H} 3 \mathrm{~N} 2$, equine-origin $\mathrm{H} 3 \mathrm{~N} 8$, human-origin $\mathrm{H} 3 \mathrm{~N} 2$, and H1N1/2009 Canine Influenza viruses. PLoS ONE 12:e0170374. https://doi.org/10.1371/journal.pone.0170374

Wang J, Tai W, Angione SL, John AR, Opal SM, Artenstein AW, Tripathi A (2013) Subtyping clinical specimens of influenza A virus by use of a simple method to amplify RNA targets. J Clin Microbiol 51:3324-3330. https://doi.org/10.1128/JCM.01206-13

Wang R, Schwartzman LM, Memoli MJ, Taubenberger JK (2011) Detection of seasonal H3N2 influenza A virus by type-specific TaqMan minor groove binder probe assay. Diagn Microbiol Infect Dis 70:281-284. https://doi.org/10.1016/j.diagmicrob io.2011.01.012

Wang S, Taaffe J, Parker C, Solórzano A, Cao H, García-Sastre A, Lu S (2006) Hemagglutinin (HA) proteins from $\mathrm{H} 1$ and $\mathrm{H} 3$ serotypes of influenza A viruses require different antigen designs for the induction of optimal protective antibody responses as studied by codonoptimized HA DNA vaccines. J Virol 80(23):11628-11637. https ://doi.org/10.1128/JVI.01065-06

Wang YF, Chang CF, Tsai HP, Chi CY, Su IJ, Wang JR (2015) Glycan-binding preferences and genetic evolution of human seasonal influenza A (H3N2) viruses during 1999-2007 in Taiwan. PLoS ONE 13(5):e0196727. https://doi.org/10.1371/journal.pone.01967 27

Wang YY, Harit D, Subramani DB, Arora H, Kumar PA, Lai SK (2017) Influenza-binding antibodies immobilise influenza viruses in fresh human airway mucus. Eur Respir J 49:160-170. https://doi. org/10.1183/13993003.01709-2016

Westgeest KB, Russell CA, Lin X, Spronken MIJ, Bestebroer TM, Bahl J, Van Beek R, Skepner E, Halpin RA, De Jong JC, Rimmelzwaan GF, Osterhaus ADME, Smith DJ, Wentworth DE, Fouchier RAM, Graaf D (2014) Genomewide analysis of reassortment and evolution of human influenza A (H3N2) viruses circulating between 1968 and 2011. J Virol 88:2844-2857. https://doi.org/10.1128/ JVI.02163-13

Wilson DS, Szostak JW (1999) In vitro selection of functional nucleic acids. Annu Rev Biochem 68:611-647. https://doi.org/10.1146/ annurev.biochem.68.1.611

Wong CL, Chan JY, Choo LX, Lim HQ, Mittman H, Olivo M (2019) Plasmonic contrast imaging biosensor for the detection of H3N2 influenza protein-antibody and DNA-DNA molecular binding. IEEE Sens J 19:11828-11833. https://doi.org/10.1109/ JSEN.2019.2936623

Wu LT, Curran MD, Ellis JS, Parmar S, Ritchie AV, Sharma PI, Allain JP, Jalal H, Zambon M, Lee HH (2010) Nucleic acid dipstick test for molecular diagnosis of pandemic H1N1. J Clin Microbiol 48:3608-3613. https://doi.org/10.1128/JCM.00981-10

Wu NC, Otwinowski J, Thompson AJ, Nourmohammad A, Wilson IA, Nycholat CM (2020) Major antigenic site B of human influenza $\mathrm{H} 3 \mathrm{~N} 2$ viruses has an evolving local fitness landscape. Nat Commun 11:1-10. https://doi.org/10.1038/s41467-020-15102-5

Yang H, Carney PJ, Chang JC, Guo Z, Villanueva JM, Stevens J (2015) Structure and receptor binding preferences of recombinant human A (H3N2) virus hemagglutinins. Virology 477:18-31. https://doi. org/10.1016/j.virol.2014.12.024

Zhang P, Vemula SV, Zhao J, Du B, Mohan H, Liu J, El Mubarak HS, Landry ML, Hewlett I (2014) A highly sensitive europium nanoparticle-based immunoassay for detection of influenza A/B virus antigen in clinical specimens. J Clin Microbiol 52:4385-4387. https://doi.org/10.1128/JCM.02635-14 